\title{
Diagnostic Work-Up of Pleural Effusions
}

\author{
Marios E. Froudarakis \\ Department of Pneumonology, Medical School of Alexandroupolis, Democritus University of Thrace, \\ Alexandroupolis, Greece
}

\section{Key Words}

Pleural effusion, diagnosis · Cytology $\cdot$ Thoracoscopy

\begin{abstract}
A wide range of diseases may be the cause of an accumulation of fluid in the pleural space. Pleural effusion is a major diagnostic problem, since the pleura is an inner cavity with no direct access. The aim of this review is to provide a practical approach to the investigation of the patient presenting with pleural effusion. This should help to accurately diagnose pleural effusion and keep time-consuming, but necessary, invasive investigations to the minimum.
\end{abstract}

Copyright $\odot 2008$ S. Karger AG, Base

\section{Introduction}

The pleural space normally contains between 7 and 16 $\mathrm{ml}$ of fluid. Any accumulation of fluid in the pleural space is the result of an increased production exceeding the rate of fluid removal [1]. Pleural effusion as initial manifestation in a patient without accompanying symptoms is a major diagnostic problem. A large number of diseases may be the cause of pleural effusion. Different pathogenetic mechanisms are involved in the creation of pleural effusion: elevated hydrostatic pressure gradient (transudation); increased extravasation of the pleural vessels (exudation) due to a local inflammatory/infiltrative process; decrease in lymphatic drainage caused by a mechanical obstruction, and decreased oncotic pressure $[1,2]$.

\section{KARGER}

Fax +41613061234 E-Mail karger@karger.ch www.karger.com
(C) 2008 S. Karger AG, Base 0025-7931/08/0751-0004\$24.50/0

Accessible online at: www.karger.com/res
Time may be wasted before an accurate diagnosis is made in patients with pleural effusion, as the pleura is an inner cavity with no direct access, adding some difficulty to the diagnosis. The aim of this review is to provide a practical approach to the investigation of the patient presenting with pleural effusion as an initial manifestation. This should assist in accurate diagnosis, keeping the number of time-consuming, but sometimes necessary, invasive investigations to a minimum.

\section{Clinical History and Assessment}

Pleural effusion may initially be present with or without associated symptoms, with or without a previously known cause, or as a pleural effusion in the evolution of a known disease. Therefore an initial clinical assessment with detailed history should be directed at identifying clues to the possible underlying cause of pleural effusion $[3,4]$. The diagnostic approach must be specific to each case as the patient's therapy and prognosis relies on this. A second practical issue is to consider whether there is bilateral pleural effusion, as this is strongly suggestive of transudate, and therefore no thoracentesis needs to be performed [3].

The etiology of pleural effusion may be pleural, pulmonary or extrapulmonary (table 1). Symptoms and signs may be specific to the respiratory system, or nonspecific general ones. Dyspnea is a major, although nonspecific, respiratory symptom which accompanies pleural effusion, commonly with progressive worsening [3, 4]. It is present in up to $50 \%$ of patients with malignant

Marios E. Froudarakis MD, $\mathrm{PhD}$

Department of Pneumonology, Medical School of Alexandroupolis

Democritus University of Thrace

GR-68100 Alexandroupolis (Greece)

Tel. +30 255107 5335, Fax +30 255107 5096, E-Mail mfroud@med.duth.gr 
Table 1. Causes of pleural effusion

Transudates
Congestive heart failure
Cirrhotic liver disease
Renal failure
Nephrotic syndrome
Hypoalbuminemia
Atelectasis
Hypothyroidism
Pulmonary embolism (10-20\%)
Malignancy (5\%)
Exudates
Parapneumonic effusion - empyema
Malignancy
Mesothelioma
Tuberculosis
Pulmonary embolism
Connective tissue disorders
Pancreatitis
Drug-induced
Post-coronary artery bypass surgery
Chylothorax
Esophageal rupture
Asbestos-related benign pleuritis
Sub-diaphragmatic abscess
Paragonimiasis
Ovarian hyperstimulation syndrome
Yellow-nail syndrome

pleural effusion [5]. The pathogenesis of dyspnea caused by a large pleural effusion has not been clearly elucidated but several factors may be involved, including a decrease in the compliance of the chest wall, contralateral shifting of the mediastinum, a decrease in ipsilateral lung volume, and reflex stimulation from the lungs and chest wall $[5,6]$.

The presence of chest pain may be helpful diagnostically as it implies a degree of inflammatory process suggestive of exudate such as pleural infection, mesothelioma, or pulmonary infarction $[3,7]$. Hemoptysis may also help in the diagnosis of associated endotracheal and/or endobronchial lesions [5, 8] or pulmonary embolism [9]. Cough is a nonspecific symptom that may involve both the lungs and pleura. History may also provide useful information, such as exposure to asbestos suggesting mesothelioma or drug-induced pleural effusion [10, 11]. Specific exposure may be overlooked by the patient and it is important to elicit and document any occupational exposure, although sometimes difficult [10]. Drugs may also occasionally be a cause of misdiagnosed pleural effusion $[3,11,12]$. The website www.pneumotox.com provides an exhaustive list of drugs causing pleural effusion (table 2).

Diagnosis of Pleural Effusion
Table 2. Common drugs and therapies causing pleural effusion (www.pneumotox.com)

\author{
Amiodarone \\ Bromocriptine \\ Carbamazepine \\ Cyclophosphamide \\ Ergots \\ Granulocyte colony-stimulating factor \\ Methotrexate \\ Nitrofurantoine \\ Penicillamine \\ Phenytoine \\ Procainamide \\ Propylthiouracil \\ Radiation therapy \\ Sulfamides
}

Constitutional nonspecific symptoms, such as fever, night sweats, weight loss, anorexia and restriction of daily activity, may be associated $[5,13,14]$. A great deal of pulmonary and extrapulmonary diseases may give the same symptomatology. Malignancies, such as lung cancer, breast cancer, gastric cancer, ovarian cancer and lymphoma, are often the cause of pleural disease either as an initial manifestation or during disease progression $[5,8,15]$. Connective tissue disorders may also be associated with pleural effusion and their existence should be systematically searched for by meticulous interrogation $[13,16]$.

Physical examination must be complete, searching for signs that may give a diagnostic clue. Typically on physical examination of the chest, a pleural syndrome is confirmed by the chest radiograph, which shows the extent of the pleural effusion [3, 4]. About $25 \%$ of the patients are totally asymptomatic and pleural effusion is discovered only after a routine chest radiograph [17]. The synthesis of the symptoms and signs from the clinical assessment and history must at least suggest the differential diagnosis in up to $75 \%$ of the cases, differentiating between the possibility and probability of a transudate or exudate [13]. Table 1 shows the causes of pleural effusion.

\section{Imaging}

\section{Chest Radiography}

The postero-anterior chest radiography is abnormal when pleural fluid is $>200 \mathrm{ml}$. In addition, the lateral radiography may show blunting of the posterior costo-diaphragmatic angle when the fluid exceeds $50 \mathrm{ml}$. The pres- 


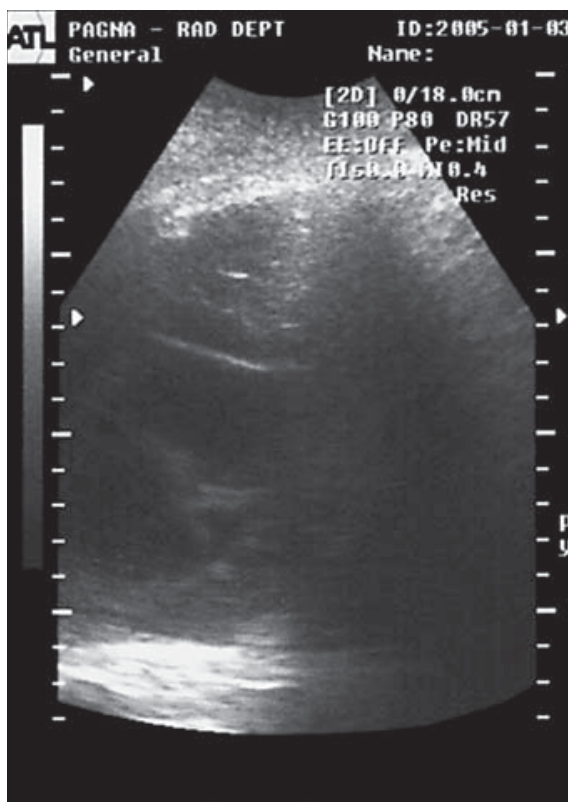

Fig. 1. Chest ultrasonography of a 44-year-old male patient showing multiple loculations.

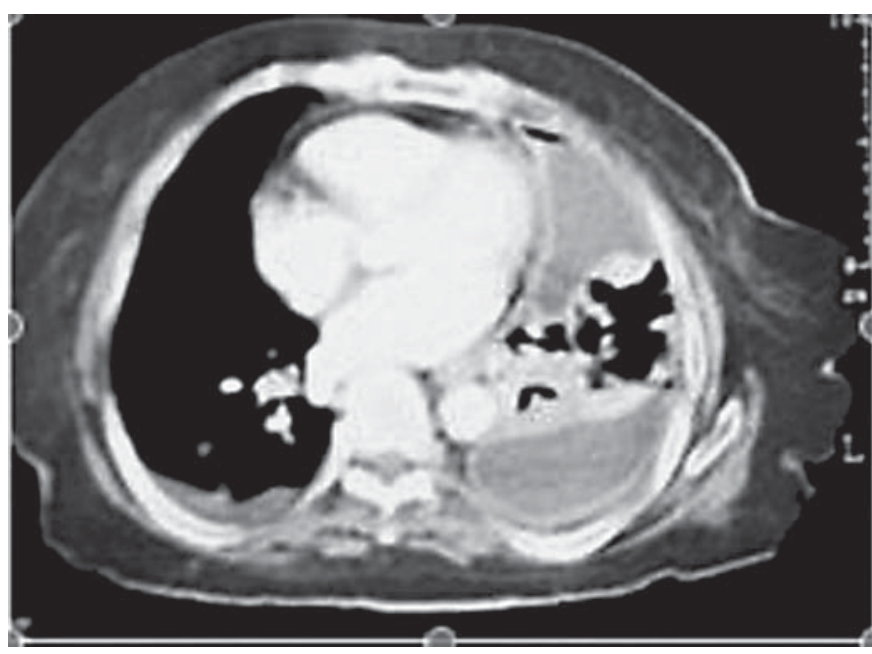

Fig. 2. Chest computed tomography of a 76-year-old female patient showing an empyema with pleural thickening involving both the parietal and visceral pleura.

ence of massive effusion will lead to a malignant etiology. Furthermore, chest radiography may show additional lesions, either pleural (pleural thickening, plaques, masses), pulmonary parenchymal (consolidation, atelectasis, tumor, diffuse reticulonodular), or mediastinal (enlargement), that will direct diagnosis [17].

\section{Chest Ultrasound}

Ultrasonography (US) will detect the presence of as little as $5-50 \mathrm{ml}$ of pleural fluid and is $100 \%$ sensitive for effusions $[17,18]$. The superiority of US is particularly apparent for small or loculated effusions [19]. Effusions with loculations and fibrous septa may appear as mass lesions on the chest radiograph as fluid climbs into the fissure. Chest ultrasound is helpful in this case (fig. 1). It may also detect tumors in relation with the parietal pleura and the chest wall, aiding biopsy with significant diagnostic yield, low complication rate and cost [19]. Overall, chest US is an important bedside tool in the detection and diagnosis of pleural effusion $[17,20]$.

\section{Chest Computed Tomography}

Computed tomography (CT) of the chest is unequaled in its ability to image the entire pleural space [20]. CT also has the advantage of simultaneously imaging the pulmonary parenchyma and mediastinum. CT is more sensitive than both conventional chest radiography and US for differentiating pleural fluid from pleural thickening and for the identification of focal masses involving the pleura or the chest wall [20] (fig. 2). When more detailed information about the pleural space in relation to other intrathoracic structures is required, CT is superior to US [20].

\section{Magnetic Resonance Imaging}

Magnetic resonance imaging has a limited role in the investigation of pleural disease due to poor spatial resolution and motion artifacts [18]. T1-weighted images, obtained after intravenous gadolinium contrast medium, can occasionally be of value in detecting pleural enhancement [18].

\section{Pleural Thoracentesis}

Not all patients with pleural effusion should undergo thoracentesis [3]. Obviously patients presenting with transudative effusion according to the history and clinical assessment, such as heart, renal and hepatic failure, should not undergo thoracentesis unless adequate treatment fails. Upon presentation, patients with diseases that may express exudative effusion, such as pulmonary infarction, pancreatitis and connective tissue disorders, should not undergo pleural fluid analysis.

When thoracentesis is considered, pleural fluid must be analyzed for pleural lactate dehydrogenase (LDH) and proteins in order to establish an exudate or a transudate according to Light's [21] criteria (table 3), pleural pH, Gram, 
acid-fast bacilli stains and cultures, and cytological analysis. Together with the analysis of the pleural fluid it is important to note the appearance of the fluid that may give important information about the origin of the effusion.

\section{Appearance}

The appearance of the pleural fluid might be useful. Massive and hemorrhagic or sero-hemorrhagic pleural effusions are likely to be malignant [22]. Pus is characteristic of pleural empyema and cloudy fluid may be due to parapneumonic pleural effusion and/or to empyema. An underlying disease such as lung carcinoma should be systematically researched. A chocolate or gelatinous pleural fluid may be the consequence of paragonimiasis. A greencolored fluid may indicate rheumatoid effusion and a 'milky' appearance chylothorax. Classically transudates are limpid, clear yellow-colored fluids. It is also important to smell the pleural fluid because an unpleasant smell suggests infection by anaerobic bacteria [23].

\section{Pleural Fluid Biochemical Analysis}

The first question to be stressed is: is this fluid an exudate? The answer in most cases is given by pleural protein. Exudates have a higher protein concentration $(>30$ $\mathrm{g} / \mathrm{l})$ due to an increase in capillary permeability and/or impaired lymphatic drainage $[24,25]$. Pleural fluid protein measurements should be interpreted in light of the serum protein. In cases with abnormal serum protein or pleural fluid protein levels close to $30 \mathrm{~g} / \mathrm{l}$, the ratio pleural/serum LDH according to Light's [21] criteria (table 3) is highly sensitive (98\%) for the diagnosis of exudates, with $83 \%$ specificity [26]. To date, no other fluid parameters studied to separate transudates from exudates have given such increased accuracy as Light's criteria [24, 27, 28]. However, rarely it may misidentify a transudative effusion as an exudate, commonly in heart or renal failure patients treated with diuretics. In such cases other criteria such as pleural fluid cholesterol determination have been recommended. A value of $>60 \mathrm{mg} / \mathrm{dl}(1.55 \mathrm{mmol} / \mathrm{l})$ is indicative of exudates [29].

A low pleural fluid $\mathrm{pH}(<7.3)$ may follow bacterial metabolism and is often associated with a reduced pleural fluid glucose $(<3.3 \mathrm{mmol} / \mathrm{l})$ or pleural fluid/serum glucose ratio of $<0.5$. This combination is relatively specific for parapneumonic pleural effusions and/or empyemas, but may be seen also in case of rheumatoid, lupus pleural effusions or in malignant pleural effusions due to tumor cell metabolism. A pleural fluid/serum rheumatoid fac-
Table 3. Light's [21] criteria differentiating exudates and transudates

The pleural fluid is an exudate if one or more of the following criteria are met:

Ratio pleural fluid protein/serum protein $>0.5$

Ratio pleural fluid LDH/serum LDH $>0.6$

Pleural fluid LDH more than two thirds the upper limit of normal serum LDH

tor ratio of $\geq 1$ can confirm the diagnosis of rheumatoid effusion in patients with clinical symptoms of the disease [30]. Patients with pleural effusions caused by systemic lupus erythematosus usually have pleural fluid/serum antinuclear antibody ratios of $>1$. The levels of complement in pleural fluid are low in both rheumatoid and lupus pleural effusions [31]. Pleural effusion of rheumatoid arthritis and systemic lupus erythematosus commonly resolves after adequate treatment of the disease $[16,23]$.

An increase in intrapleural amylase is characteristic of effusion due to pancreatitis but also may be found in pleural effusion caused by esophageal disruption. The disruption or obstruction of the thoracic duct by a tumor or trauma may result in a chylothorax with the characteristic 'milky' pleural fluid. Confirmation of chylothorax is made by determining the levels of triglycerides in the fluid, which must be $>110 \mathrm{mg} / \mathrm{dl}$, and contain chylomicrons but not cholesterol crystals [32].

\section{Pleural Fluid Microbiologic Analysis}

Pneumonia is associated with an exudative pleural effusion in up to $57 \%$ of cases and is the most common cause of pleural effusion in young patients. Resolution is obtained with antibiotic treatment, but a certain number will progress to an infected pleural space $[33,34]$. Significant progress in the treatment of complicated parapneumonic effusion has been shown with the use of intrapleural fibrinolytics [35, 36]. However, the mortality from empyema is as high as $15 \%$ and up to $40 \%$ of these patients require surgery because medical treatment has failed [33]. Therefore rapid recognition of such patients is important. The bacteriology of pleural infection varies as there are significant differences between community- and hospital-acquired infections [37, 38].

Thoracentesis is essential for a diagnosis of pleural infection. Aspiration may be difficult in empyema or loculated effusions (fig. 3). In such cases chest US should be 


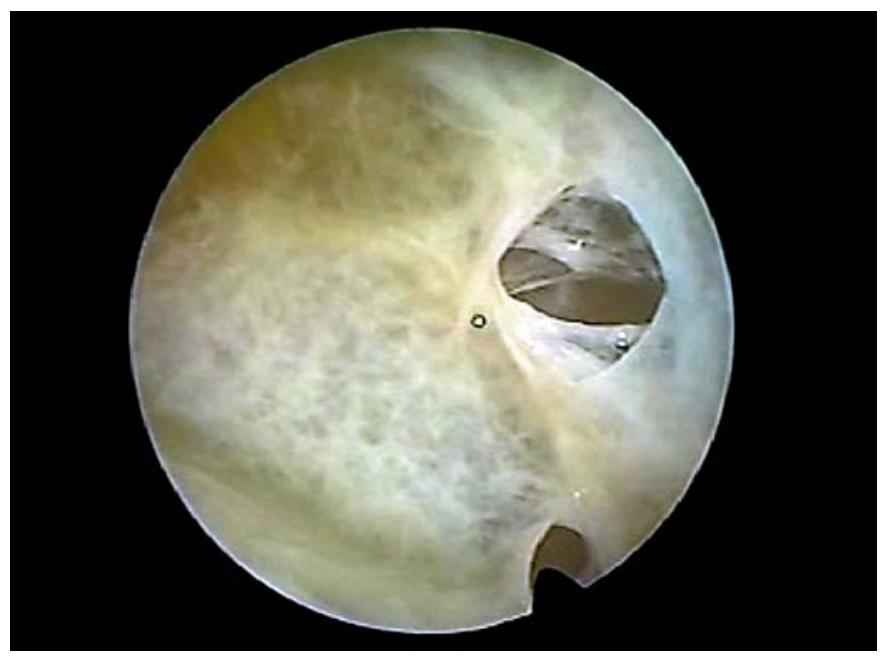

Fig. 3. Loculations seen during thoracoscopy in a 36-year-old male patient with complicated parapneumonic effusion.

used to localize pleural fluid. The appearance of the fluid must be noted and samples must be taken for Gram's stain and culture [34, 38]. Another sample should be collected in a heparinized syringe to determine pleural fluid $\mathrm{pH}$ in a blood gas machine, but only in non-purulent pleural infections [38]. However, pleural fluid cultures are negative in up to $30 \%$ of the cases of infection, because either the patient has already received previous antibiotic treatment or the aspiration fluid was not adequately manipulated. Diagnostic accuracy may be increased by analyzing fluid samples in blood culture bottles [34, 37].

Diagnosis is confirmed with a frankly purulent pleural fluid and/or the presence of microbes on Gram's stain or culture [33]. When those criteria are not met, the patient's clinical presentation associated with a $\mathrm{pH}$ of $<7.20$ is suggestive of pleural infection [33]. In pleural infections with multiple loculations [28] and/or a Proteus mirabilis infection [39], the possibility of aspirating fluid from a compartment that has a $\mathrm{pH}$ of $>7.20$ should not exclude a complicated parapneumonic effusion, which may also be supported by increased pleural LDH $(>1,000$ IU/l) and low glucose $(<35 \mathrm{mg} / \mathrm{dl})[34,38]$.

Common causes of community-acquired infection include the Streptococcus milleri group (including S. intermedius, S. constellatus and S. inonia), Streptococcus pneumoniae and staphylococci, sometimes with associated anaerobes [37, 38]. Less common organisms responsible include other streptococci, enterobacteria, Haemophilus influenzae, Pseudomonas spp., tuberculosis and Nocardia. Hospital-acquired infection, mostly due to pneumo- nia, surgery, trauma or pleural procedures, is frequently caused by methicillin-resistant Staphylococcus aureus or enterobacteria [37].

In TB effusions, fluid smears and culture have a low yield (10-20 and 25-50\%, respectively) [40]. Culture of pleural fluid and biopsy improves the diagnostic yield to about 90\% [40, 41]. Pleural fluid adenosine deaminase (ADA) may be raised but is nonspecific or negative in HIV infection and is of value in high endemic areas [41, 42]. In association with increased lymphocytes, ADA has $95 \%$ sensitivity and $89 \%$ specificity in tuberculous pleurisy [43]. Anti-TB treatment is reasonable to consider in the undiagnosed recurrent effusion with a positive tuberculin test (positive in $70 \%$ of TB effusions) with a lymphocytic exudate [41].

\section{Pleural Fluid Cytological Analysis}

Differential cell counting adds little diagnostic information. Pleural lymphocytosis is common in malignant and tuberculous effusions but can also be attributable to rheumatoid disease, lymphoma, sarcoidosis, and chylothorax. Eosinophilic ( $>10 \%$ eosinophils) pleural effusions are often benign, associated with blood or air in the pleural space, but can be attributable to underlying malignancy in up to $10 \%$ of cases and therefore still need to be investigated fully [44]. Causes of pleural eosinophilia include parapneumonic effusion, benign asbestos pleural effusion, Churg-Strauss syndrome, pulmonary infarction, parasitic disease, and drugs. Coronary artery bypass grafting may also cause early left-sided, hemorrhagic, eosinophilic pleural effusions followed later by small lymphocyte predominant effusions $[45,46]$.

Morphologic analysis of the cells recovered from an effusion may not be sufficient to reach a diagnosis of malignancy $[47,48]$. Commonly, the distinction between atypical mesothelial cells and metastatic carcinoma is impossible because of the notorious reactivity of mesothelial cells [47]. When considering the primary site of a metastatic malignancy three factors are crucial: (1) the type of cell present in the effusion; (2) the location of the effusion in relation to the age and sex of the patient, and (3) the presence and nature of a tumor in a distant site [47]. If any of these three crucial data is missing, the puzzle may be resolved by astute interpretation of cytologic details and the use of ancillary methods such as immunocytochemistry [47].

Pleural fluid cytology is the simplest definitive method to obtain a diagnosis of malignant pleural effusion. 
Malignant effusions can be diagnosed by a single pleural fluid cytology specimen in $60 \%$ of the cases for carcinomatous effusions but only $20-30 \%$ for mesothelioma [48] . This yield is only slightly increased if repeated cytology specimens are analyzed [48]. The cytological yield is higher for adenocarcinoma and when smears and blocks are used [48]. Overall, the diagnostic yield of pleural cytology shows large variation in different series. The diagnostic yield is dependent on such factors as the extent of disease and the nature of the primary malignancy [5]. Immunohistochemical epithelial and glandular markers may help to confirm epithelial malignancy and differentiate mesothelioma from adenocarcinoma [48].

\section{Other Markers}

Several tumor markers, such as carcinoembryonic antigen, CA-125, CA-19-9, CYFRA 21-1, nonspecific enolase, have been tested in patients with malignant pleural effusion [49-51]. Although the results seem to be controversial as to the usefulness of these tumor markers in the differential diagnosis of pleural effusions, even between malignant and nonmalignant, some authors propose specific tumor markers for the diagnosis of pleural effusions due to bronchogenic carcinoma $[52,53]$. A reasonable attitude may be that tests should be performed in a selected population of patients with negative cytology and 'suspect' clinical outcome [54].

There are a number of studies on various novel markers, such as acute phase proteins [55], oncogenes [56], cytokines involved in inflammation [57, 58], and matrix metalloproteinases [59], in the differential diagnosis between transudates and exudates and/or between malignant and benign pleural effusions. Although some may be adequate markers for pleural effusion differentiation, they are not as sensitive, specific, or cost- and time-efficient as the easily available standard tests [60]. Biochemical or biological markers in malignant pleural effusions, as well as in the serum, cannot replace routine cytopathologic examination in the diagnosis of the disease and predicting the outcome of the patient without firm diagnosis [61].

\section{Pleural Biopsy Procedures}

\section{Blind Pleural Biopsy}

The diagnostic yield of closed pleural biopsy alone in malignant pleural effusions is about the same as pleural cytology. A combination of both techniques seems to im- prove diagnostic yield $[5,62]$. The low diagnostic yield of closed pleural biopsy is due to factors such as early stage disease with small pleural extension, location of tumors in areas of the pleura unreachable by the needle, including the visceral pleura [63], as well as the inexperience of the physician [64]. The diagnostic yield of blind biopsy increases with the number of specimens taken in malignant pleural effusion [65]; at least 4 biopsy samples are needed for accurate diagnosis [65]. As pleural invasion is preferentially located at the base of the hemithorax, it is recommended that the sample be taken from the lowest part of the costal pleura in order to achieve a higher diagnostic success $[63,66]$.

In benign pleural effusion the diagnostic yield of blind pleural biopsy depends on the etiology. For tuberculous pleurisy the diagnostic accuracy is about $100 \%$ when it is associated with culture of acid-fast bacteria, as well as in combination with pleural ADA and a lymphocyte/neutrophil ratio of $\geq 0.75$ [43]. In patients with suspected $\mathrm{TB}$ pleurisy, one biopsy sample might be sufficient for diagnosis, as multiple samples do not increase the diagnostic yield since the disease is widely spread in the pleural cavity [65].

In connective tissue disorders associated with pleural effusion, blind biopsies offer little to the diagnosis as typical histological findings of the disease are occasionally found. Most patients present a nonspecific histological appearance of chronic and/or granulomatous or fibrotic pleuritis [67]. However, patients with pleural effusion associated with connective tissue disorders are more likely to be diagnosed according to the associated findings on clinical presentation and/or laboratory tests. Studies are lacking to evaluate the diagnostic accuracy of different bioptic techniques in such patients.

\section{Thoracoscopy}

Thoracoscopy is the 'gold standard' in the diagnosis of pleural effusion as it is indicated when less invasive tests have failed $[3,68-70]$. It is a simple and safe method with a diagnostic yield of 93-97\% [71-74] in patients with malignant pleural effusion. The method is performed either under local or general anesthesia by one or two ports of entry $[75,76]$. Before thoracoscopy is indicated, and to avoid complications, the performance status of the patient should be considered together with limitations such as coagulation problems, with or without anticoagulant therapy, thrombocytopenia, severe respiratory insufficiency with hypercapnea, and unstable cardiac status.

In developed countries, thoracoscopy is very important as there is a significant likelihood of malignancy in 


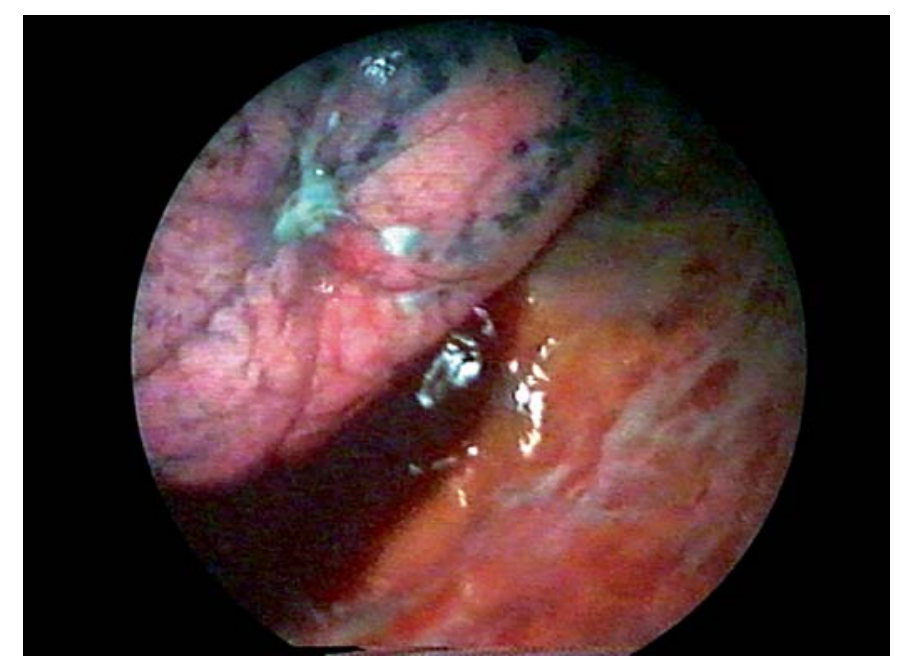

Fig. 4. Peripheral lung adenocarcinoma of the left lower lobe with satellite nodules on the visceral pleura also invading the parietal pleura in a 41-year-old male patient.

Table 4. Primary tumor site in patients with malignant pleural effusion

$\begin{array}{lr}\text { Lung carcinoma } & 37.5 \% \\ \text { Breast carcinoma } & 16.8 \% \\ \text { Lymphoma } & 11.5 \% \\ \text { Genitourinary carcinomas } & 9.4 \% \\ \text { Gastrointestinal carcinomas } & 6.9 \% \\ \text { Other carcinomas } & 7.3 \% \\ \text { Unknown primary } & 10.7 \%\end{array}$

Modified from Antunes et al. [91].

patients with undiagnosed pleural effusions [13]. Indeed, in developed countries where the incidence of tuberculosis is low, more than $50 \%$ of the cases of undiagnosed pleural effusion are due to carcinomas, the second most common (10\%) being tuberculosis [71, 77, 78]. After thoracoscopy less than $10 \%$ of the cases of initially suspected pleural effusion are diagnosed as having nonspecific (idiopathic) pleuritis $[71,77]$. During the follow-up period of those with nonspecific pleuritis, only $4-8 \%$ of patients present a malignancy after repeated thoracoscopies $[79$, 80]. Most of the cases (up to 80\%) follow a true benign course with spontaneous resolution, while few cases are 'idiopathic' $[79,80]$.

Thoracoscopy also provides information on the extent of underlying diseases such as lung carcinoma $[8,74,81]$ and mesothelioma $[82,83]$. In case of lung cancer, thoracoscopy is performed not only to diagnose but also to

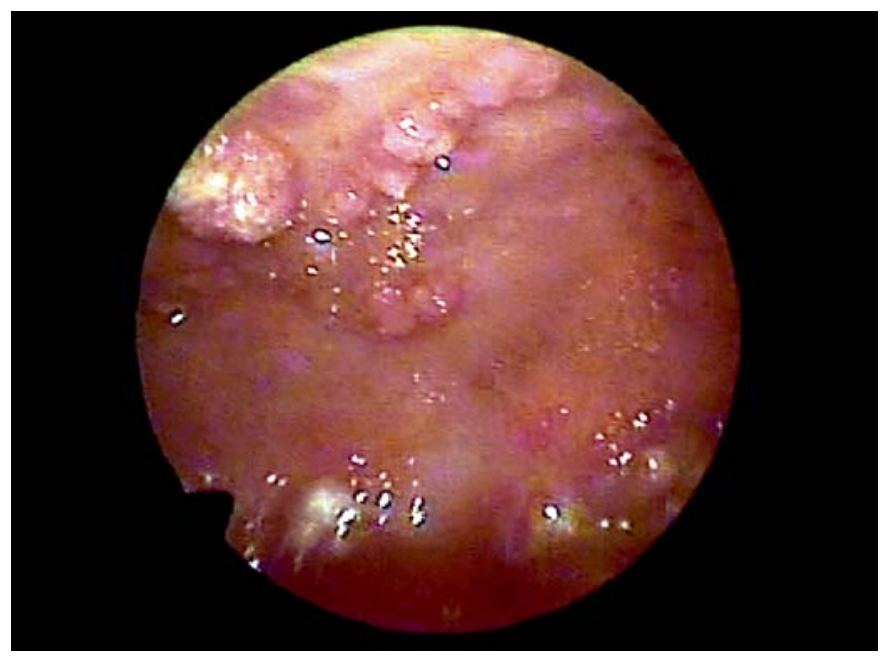

Fig. 5. Masses from an epithelial mesothelioma of the parietal pleura in a 56-year-old patient.

detect pleural infiltration (fig. 4) and, for non-small-cell lung carcinoma, to determine T4 stage disease, which excludes surgical resection and indicates a poor prognosis for the patient $[8,81,84]$. The role of thoracoscopy in early stage mesothelioma is essential to determine the use of multimodality treatment based on extrapleural pneumonectomy [82]. Thoracoscopy in mesothelioma (fig. 5) is also necessary in advanced stage disease to diagnose and map lesions of the pleural cavity in order to evaluate the possible treatment response with a 'second look' [83].

Thoracoscopy with talc poudrage, under local anesthesia, provides palliation of dyspnea and discomfort due to the amount of pleural effusion in malignancies. Although the ideal sclerosing agent has not yet been found [85], talc poudrage is a safe, low-cost and more efficient method than pleurodesis (up to $90 \%$ success) $[86,87]$ and has mild side effects such as fever $[87,88]$.

\section{Bronchoscopy}

When an endotracheal and/or endobronchial lesion is suspected, fiberoptic bronchoscopy is indicated [89]. After initial workup, pleural effusion of unknown origin is associated with bronchogenic carcinoma in more than $30 \%$ of the cases [89-91] (table 4). Also, fiberoptic bronchoscopy is useful in assessing the extent of the disease in the tracheobronchial tree, which is important for treatment and prognosis [89]. 
Fig. 6. Pleural effusion work-up.

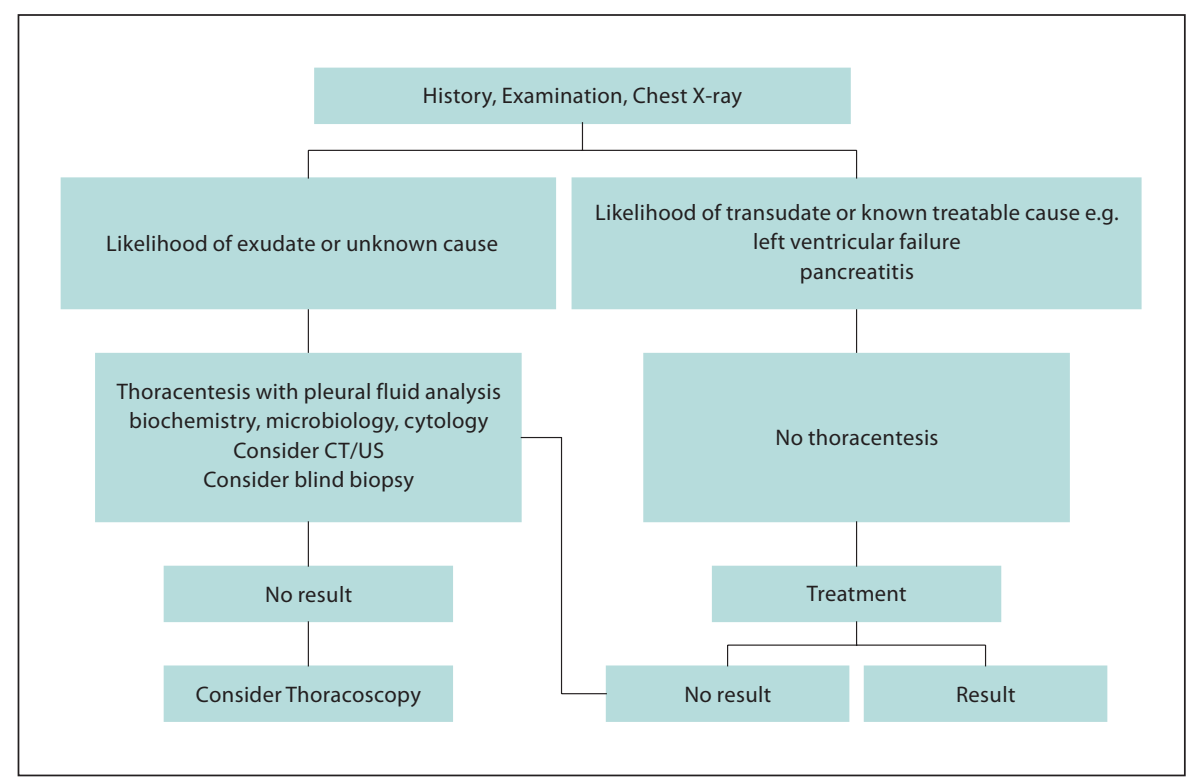

\section{Conclusion}

The diagnosis of pleural effusion is difficult, as the pleura is an inner cavity with no direct access. The various noninvasive diagnostic techniques are of limited diagnostic yield and generally very much dependent on the underlying disease, the disease distribution in the pleural cavity, and the experience of the physicians. These are the main reasons why time is wasted before diagnosis in patients with pleural effusion. This delay in diagnosis might lead to important 'side effects' such as inadequate treatment and poor prognosis, together with discomfort and deterioration in the quality of life of the patient.

Thoracoscopy, performed under local anesthesia in the endoscopy suite, gives solutions in more than $95 \%$ of undiagnosed pleural effusions, with minimal and mild complications. It is a method widely applied by many respiratory physicians to whom a patient with pleural effusion must be referred immediately after a negative initial work-up (fig. 6).

\section{References}

1 Miserocchi G: Physiology and pathophysiology of pleural fluid turnover. Eur Respir J 1997;10:219-225.

$\checkmark 2$ Sahn SA: Pleural diagnostic techniques. Am Rev Respir Dis 1988;138:184-234.

3 Maskell NA, Butland RJA: BTS guidelines for the investigation of a unilateral pleural effusion in adults. Thorax 2003;58(suppl 2): ii8-iil7.

4 Rahman NM, Chapman SJ, Davies RJ: Pleural effusion: a structured approach to care. Br Med Bull 2004;72:31-47.

5 Antony VB, Loddenkemper R, Astoul P, Boutin C, Goldstraw P, Hott J, Rodriguez Panadero F, Sahn SA: Management of malignant pleural effusions. Eur Respir J 2001;18: 402-419.
-6 Estenne M, Yernault JC, DeTroyer A: Mechanism of relief of dyspnea after thoracocentesis in patients with large pleural effusions. Am J Med 1983;74:813-819.

7 Judson MA, Sahn SA: Pulmonary physiologic abnormalities caused by pleural disease. Semin Respir Crit Care Med 1995;16:346353.

8 Froudarakis ME, Fournel P: Pleural effusion in lung carcinoma; in Bouros D (ed): Pleural Diseases. New York, Dekker, 2004, pp 439456.

$\checkmark 9$ Light RW: Pleural effusion due to pulmonary emboli. Curr Opin Pulm Med 2001;7:198201.

10 Becklake MR, Bagatin E, Neder JA: Asbestos-related diseases of the lungs and pleura: uses, trends and management over the last century. Int J Tuberc Lung Dis 2007;11:356369.
11 Gallardo X, Castaner E, Mata JM: Benign pleural diseases. Eur J Radiol 2000;34:8797.

12 Antony VB: Drug-induced pleural disease. Clin Chest Med 1998;19:331-340.

13 Light RW: The undiagnosed pleural effusion. Clin Chest Med 2006;27:309-319.

14 Sahn SA: Malignancy metastatic to the pleura. Clin Chest Med 1998;19:351-361.

15 Davidson B: Malignant effusions: from diagnosis to biology. Diagn Cytopathol 2004;31: 246-254.

16 Joseph J, Sahn SA: Connective tissue diseases and the pleura. Chest 1993;104:262-270.

17 Qureshi NR, Gleeson FV: Imaging of pleural disease. Clin Chest Med 2006;27:193-213.

18 Evans AL, Gleeson FV: Radiology in pleural disease: state of the art. Respirology 2004;9: 300-312. 
19 Tsai TH, Yang PC: Ultrasound in the diagnosis and management of pleural disease. Curr Opin Pulm Med 2003;9:282-290.

20 McLoud TC, Flower CDR: Imaging the pleura: sonognaphy, CT, and MR imaging. AJR Am J Roentgenol 1991;156:1145-1153.

21 Light RW: Pleural Diseases, ed 4. Baltimore, Lippincott, Williams \& Wilkins, 2001.

22 Martensson G, Pettersson K, Thiringer G: Differentiation between malignant and nonmalignant pleural effusion. Eur J Respir Dis 1985;67:326-334.

23 Ferrer J, Roldan J: Clinical management of the patient with pleural effusion. Eur J Radiol 2000;34:76-86.

24 Heffner JE: Discriminating between transudates and exudates. Clin Chest Med 2006;27: 241-252.

25 Light RW: Useful tests on the pleural fluid in the management of patients with pleural effusions. Curr Opin Pulm Med 1999;5:245249.

26 Light RW: Pleural effusion. N Engl J Med 2002;346:1971-1977.

27 Heffner JE: Evaluating diagnostic tests in the pleural space. Differentiating transudates from exudates as a model. Clin Chest Med 1998;19:277-293.

-28 Heffner JE, Brown LK, Barbieri C, DeLeo JM: Pleural fluid chemical analysis in parapneumonic effusions. A metaanalysis. Am J Respir Crit Care Med 1995;151:1700-1708.

29 Hamm H, Brohan U, Bohmer R, Missmahl HP: Cholesterol in pleural effusions: a diagnostic aid. Chest 1987;92:296-302.

- 30 Halla JT, Schronhenholer RE, Volanakis JE: Immune complexes and other laboratory features of pleural effusions. Ann Intern Med 1980;92:748-752.

- 31 Good JT, Khare V, Baethge B, Lang S, Wolf RE, Douglas Campbell GJ: Antinuclear antibodies in pleural fluid. Chest 1994;106:866871.

- 32 Hillerdal G: Chylothorax and pseudochylothorax. Eur Respir J 1997;10:1157-1162.

33 Davies W, Kearney S, Gleeson F, Davies R: Predictors of outcome and long-term survival in patients with pleural infection. Am J Respir Crit Care Med 2003;160:1682-1686.

34 Davies CW, Gleeson FV, Davies RJ: BTS guidelines for the management of pleural infection. Thorax 2003;58(suppl 2):ii18-ii28.

- 35 Bouros D, Schiza S, Tzanakis N, Drositis J, Siafakas N: Intrapleural urokinase in the treatment of complicated parapneumonic pleural effusions and empyema. Eur Respir J 1996;9:1656-1659.

- 36 Bouros D, Schiza S, Tzanakis N, Chalkiadakis G, Drositis J, Siafakas N: Intrapleural urokinase versus normal saline in the treatment of complicated parapneumonic effusions and empyema. A randomized, doubleblind study. Am J Respir Crit Care Med 1999; 159:37-42.

37 Davies RJ, Gleeson FV: The diagnosis and management of pleural empyema. Curr Opin Pulm Med 1998;4:185-190.
38 Chapman SJ, Davies RJ: The management of pleural space infections. Respirology 2004;9: 4-11.

39 Pine JR, Hollman JL: Elevated pleural fluid $\mathrm{pH}$ in Proteus mirabilis empyema. Chest 1983; 84:109-111.

40 Ferrer J: Pleural tuberculosis. Eur Respir J 1997;10:942-947.

41 Gopi A, Madhavan SM, Sharma SK, Sahn SA: Diagnosis and treatment of tuberculous pleural effusion in 2006. Chest 2007;131 880-889.

42 Chen ML, Yu WC, Lam CW, Au KM, Kong FY, Chan AY: Diagnostic value of pleural fluid adenosine deaminase activity in tuberculous pleurisy. Clin Chim Acta 2004;341:101107.

43 Diacon AH, Van de Wal BW, Wyser C, Smedema JP, Bezuidenhout J, Bolliger CT, Walzl G: Diagnostic tools in tuberculous pleurisy: a direct comparative study. Eur Respir J 2003;22:589-591.

44 Light RW, Erozan YS, Ball WC Jr: Cells in pleural fluid. Their value in differential diagnosis. Arch Intern Med 1973;132:854860.

45 Light RW, Rogers JT, Cheng D, Rodriguez RM: Large pleural effusions occurring after coronary artery bypass grafting. Cardiovascular Surgery Associates, PC. Ann Intern Med 1999;130:891-896.

46 Light RW: Pleural effusions after coronary artery bypass graft surgery. Curr Opin Pulm Med 2002;8:308-311.

47 Bedrossian CW: Diagnostic problems in serous effusions. Diagn Cytopathol 1998;19: 131-137.

48 Johnston WW: The malignant pleural effusion: a review of cytopathologic diagnosis of 584 specimens from 472 consecutive patients. Cancer 1985;56:905-909.

49 Alatas F, Alatas O, Metintas M, Colak O, Harmanci E, Demir S: Diagnostic value of CEA, CA 15-3, CA 19-9, CYFRA 21-1, NSE and TSA assay in pleural effusions. Lung Cancer 2001;31:9-16.

50 Cascinu S, Del Ferro E, Barbanti I, Ligi M, Fedeli A, Catalano G: Tumor markers in the diagnosis of malignant serous effusions. Am J Clin Oncol 1997;20:247-250.

51 Miedouge M, Rouzaud P, Salama G, Pujazon MC, Vincent C, Mauduyt MA, Reyre J, Carles P, Serre G: Evaluation of seven tumour markers in pleural fluid for the diagnosis of malignant effusions. Br J Cancer 1999;81: 1059-1065.

52 Menard O, Dousset B, Jacob C, Martinet Y: Improvement of the diagnosis of the cause of pleural effusion in patients with lung cancer by simultaneous quantification of carcinoembryonic antigen (CEA) and neuron-specific enolase (NSE) pleural levels. Eur J Cancer 1993;13:1806-1809.
53 Toumbis M, Rasidakis A, Passalidou E, Kalomenidis J, Alchanatis $\mathrm{M}$, Orphanidou D, Jordanoglou J: Evaluation of CYFRA 21-1 in malignant and benign pleural effusions. Anticancer Res 1996;16:2101-2104.

54 Falcone F, Marinelli M, Minguzzi L, Paganelli GM, Turba E, Cavalli A, Rapellino M: Tumor markers and lung cancer: guidelines in a cost-limited medical organization. Int J Biol Markers 1996;11:61-66.

-55 Alexandrakis MG, Coulocheri SA, Bouros D, Vlachonikolis IG, Eliopoulos GD: Significance of alpha-2-macroglobulin, alpha-1acid glycoprotein, and C-reactive protein in pleural effusion differentiation. Respiration 2000;67:30-35.

-56 Stoetzer OJ, Munker R, Darsow M, Wilmanns W: P53-immunoreactive cells in benign and malignant effusions: diagnostic value using a panel of monoclonal antibodies and comparison with CEA-staining. Oncol Rep 1999;6:455-458.

57 Alexandrakis MG, Coulocheri SA, Bouros D, Mandalaki K, Karkavitsas N, Eliopoulos GD: Evaluation of inflammatory cytokines in malignant and benign pleural effusions. Oncol Rep 2000;7:1327-1332.

-58 Alexandrakis MG, Kyriakou D, Alexandraki R, Pappa KA, Antonakis N, Bouros D: Pleural interleukin-1 beta in differentiating transudates and exudates: comparative analysis with other biochemical parameters. Respiration 2002;69:201-206.

-59 Hurewitz AN, Zucker S, Mancuso P, Wu CL, Dimassimo B, Lysik RM, Moutsiakis D: $\mathrm{Hu}-$ man pleural effusions are rich in matrix metalloproteinases. Chest 1992;102:1808-1814.

60 Antony VB: Drawing the line: differentiating transudates from exudates. Respiration 2002;69:198.

-61 Marel M, Stastny B, Melinova L, Svandova E, Light RW: Diagnosis of pleural effusions. Experience with clinical studies, 1986 to 1990. Chest 1995;107:1598-1603.

62 Edmondstone WM: Investigation of pleural effusion: comparison between fibreoptic thoracoscopy, needle biopsy and cytology. Respir Med 1990;84:23-26.

$\checkmark 63$ Canto A, Rivas J, Saumench J, Morera R, Moya J: Points to consider when choosing a biopsy method in cases of pleurisy of unknown origin. Chest 1983;84:176-179.

64 Walshe AD, Douglas JG, Kerr KM, McKean ME, Godden DJ: An audit of the clinical investigation of pleural effusion. Thorax 1992; 47:734-737.

65 Jimenez D, Perez-Rodriguez E, Diaz G, Fogue L, Light RW: Determining the optimal number of specimens to obtain with needle biopsy of the pleura. Respir Med 2002;96: $14-17$

-66 Rodriguez-Panadero F, Borderas Naranjo F, Lopez Mejias J: Pleural metastatic tumours and effusions. Frequency and pathogenic mechanisms in a post-mortem series. Eur Respir J 1989;2:366-369. 
67 Vassilakis DA, Wells AU, Bouros D: Immunological diseases of the pleura; in Bouros D (ed): Pleural Diseases. New York, Dekker, 2004, pp 595-620.

68 Colt HG: Thoracoscopy: window to the pleural space. Chest 1999;116:1409-1415.

69 Mathur PN, Astoul P, Boutin C: Medical thoracoscopy: technical details. Clin Chest Med 1995; 16:479-486.

-70 Boutin C, Astoul P: Diagnostic thoracoscopy. Clin Chest Med 1998;19:295-309.

-71 Boutin C, Viallat JR, Cargnino P, Farisse P: Thoracoscopy in malignant pleural effusions. Am Rev Respir Dis 1981;124:588592.

-72 Boutin C, Viallat JR, Cargnino P, Farisse P: Indications actuelles de la thoracoscopie. Compte rendu du Symposium de Marseille. Rev Fr Mal Respir 1981;9:309-318.

-73 Boutin C, Loddenkemper R, Astoul P: Diagnostic and therapeutic thoracoscopy: techniques and indications in pulmonary medicine. Tuber Lung Dis 1993;74:225-239.

-74 Roeslin N, Kessler R: Quelle est la place de la thoracoscopie dans le bilan d'extension préopératoire du cancer bronchique non à petites cellules? Rev Mal Respir 1992;9:R247R251.

-75 Loddenkemper R: Thoracoscopy - state of the art. Eur Respir J 1998;11:213-221.

-76 Rodriguez-Panadero F, Janssen JP, Astoul P: Thoracoscopy: general overview and place in the diagnosis and management of pleural effusion. Eur Respir J 2006;28:409-422.
77 Harris RJ, Kavuru MS, Mehta AC, Medendorp SV, Wiedemann HP, Kirby TJ, Rice TW: The impact of thoracoscopy on the management of pleural disease. Chest 1995 107:845-852.

78 Kendall SW, Bryan AJ, Large SR, Wells FC: Pleural effusions: is thoracoscopy a reliable investigation? A retrospective review. Respir Med 1992;86:437-440.

79 Venekamp LN, Velkeniers B, Noppen M: Does 'idiopathic pleuritis' exist? Natural history of non-specific pleuritis diagnosed after thoracoscopy. Respiration 2005;72:7478 .

80 Janssen JP, Ramlal S, Mravunac M: The long term follow-up of exudative pleural effusion after non-diagnostic thoracoscopy. J Bronchol 2004;11:169-174.

81 Canto A, Ferrer G, Romagosa V, Moya J, Bernat R: Lung cancer and pleural effusion. Clinical significance and study of pleural metastatic locations. Chest 1985;87:649652.

82 Scherpereel A; French Speaking Society for Chest Medicine (SPLF) Experts Group: Guidelines of the French Speaking Society for Chest Medicine for management of malignant pleural mesothelioma. Respir Med 2007;101:1265-1276.

83 Astoul P: Diagnostique clinique et endoscopique du mésothéliome pleural; in Astoul P (ed): Mésothéliome pleural. Paris, Elsevier, 2005, pp 77-88.
84 Colt HG: Thoracoscopic management of malignant pleural effusions. Clin Chest Med 1995; 16:505-518

85 Bouros D, Froudarakis M, Siafakas NM: Pleurodesis: everything flows. Chest 2000; 118:577-579.

86 Rodriguez-Panadero F, Antony VB: Pleurodesis: state of the art. Eur Respir J 1997; 10:1648-1654.

87 Janssen JP, Collier G, Astoul P, Tassi GF, Noppen M, Rodriguez-Panadero F, Loddenkemper R, Herth FJ, Gasparini S, Marquette $\mathrm{CH}$, Becke B, Froudarakis ME, Driesen P, Bolliger CT, Tschopp JM: Safety of pleurodesis with talc poudrage in malignant pleural effusion: a prospective cohort study. Lancet 2007;369:1535-1539.

88 Froudarakis ME, Klimathianaki M, Pougounias M: Systemic inflammatory reaction after thoracoscopic talc poudrage. Chest 2006;129:356-361.

89 Vergnon JM, Froudarakis M: Bronchoscopy; in Grassi C (ed): Pulmonary Diseases. London, McGraw-Hill International, 1999, pp 39-43.

90 Poe RH, Levy PC, Israel RH, Ortiz CR, Kalley MC: Use of fiberoptic bronchoscopy in the diagnosis of bronchogenic carcinoma. A study in patients with idiopathic pleural effusions. Chest 1994;105:1663-1667.

91 Antunes G, Neville E, Duffy J, Ali N: BTS guidelines for the management of malignant pleural effusions. Thorax 2003;58(suppl 2): ii29-ii38. 